\title{
A Joining Process between Beryllium and Reduced-Activation Ferritic-Martensitic Steel by Plasma Sintering
}

\author{
Jae-Hwan Kim, Taehyun Hwang * and Masaru Nakamichi
}

Citation: Kim, J.-H.; Hwang, T.; Nakamichi, M. A Joining Process between Beryllium and ReducedActivation Ferritic-Martensitic Steel by Plasma Sintering. Materials 2021, 14, 6348. https://doi.org/10.3390/ ma14216348

Academic Editors: Francisca G. Caballero and Elena Pereloma

Received: 25 September 2021

Accepted: 22 October 2021

Published: 23 October 2021

Publisher's Note: MDPI stays neutral with regard to jurisdictional claims in published maps and institutional affiliations.

Copyright: (c) 2021 by the authors. Licensee MDPI, Basel, Switzerland. This article is an open access article distributed under the terms and conditions of the Creative Commons Attribution (CC BY) license (https:// creativecommons.org/licenses/by/ $4.0 /)$.
Fusion Energy Directorate, Rokkasho Fusion Institutes, Breeding Functional Materials Development Group, National Institutes for Quantum Science and Technology, Aomori 039-3212, Japan; kim.jaehwan@qst.go.jp (J.-H.K.); nakamichi.masaru@qst.go.jp (M.N.)

* Correspondence: hwang.taehyun@qst.go.jp

\begin{abstract}
To investigate the growth kinetics of the reaction layer and mechanical strength of joined materials, we joined beryllium and reduced-activation ferritic-martensitic steel (F82H) by plasma sintering under various conditions and characterized the joined region. Scanning electron microscopy revealed that the thickness of the reaction layer increased with an increase in the joining time and temperature. Line analyses and elemental mapping using an electron microprobe analyser showed that the reaction layer consists of Be-Fe intermetallic compounds, including $\mathrm{Be}_{12} \mathrm{Fe}, \mathrm{Be}_{5} \mathrm{Fe}$, and $\mathrm{Be}_{2} \mathrm{Fe}$, with small amounts of chromium and tungsten. Owing to the time and temperature dependence of the reaction-layer thickness, the layer growth of Be-Fe intermetallic compounds obeys the parabolic law, and the activation energy for the reaction-layer growth was $116.2 \mathrm{~kJ} / \mathrm{mol}$. The bonding strengths of the joined materials varied inversely with the thickness of the reaction layer.
\end{abstract}

Keywords: beryllium; F82H; plasma sintering; intermetallic compound; bonding strength

\section{Introduction}

Great attention has been paid to technologies for joining materials, including metals, ceramics, polymers, and composites. Joining processes are promising techniques to improve specific properties, such as structural strengths and functional properties; the joined materials show more excellent properties than the individual materials $[1,2]$. Several techniques have been proposed for joining metals, including metallic brazing [3], welding [4], plasma spraying [5], and coating [6].

For fusion applications, beryllium (Be) is used as an amour for the first wall in an International Thermonuclear Experimental Reactor (ITER) owing to the advantages of low-atomic-number (Z) materials, including reduced impurity content, low loss of plasma radiation, and absence of chemical sputtering. However, Be forms intermetallic compounds with iron (Fe) [7], which may reduce the strength of the joint area since intermetallic compounds are considerably brittle.

Efforts have been made to simplify the blanket design [8] by replacing the pebbles with block-shaped neutron-multiplying materials. This can also reduce the fraction of structural steel, which may contribute to plasma disruption or electromagnetic issues. When neutron-multiplying materials are used as block shapes by partial replacement of structural materials, the obtained material has good bonding strength to structural materials, such as reduced-activation ferritic-martensitic steel. Supposing the operating temperature is not high, Be can be considered the first wall material and as a block-shaped material in the blanket region of the fusion reactor to increase the neutron-multiplying efficiency.

Hot-isostatic-press (HIP) joining Be and F82H (Japanese reduced-activation ferriticmartensitic steel) has been conducted, and the thickness and bonding strengths of the reaction layers, such as thin $\mathrm{Cr}$ [9] and Ti films [10] have been investigated. The authors have, for the first time globally, fabricated Be [11,12] and beryllium intermetallic com- 
pounds [13-15] by plasma sintering, which is an advantageous process including surface activation for cleaning, and rapid heating and cooling speeds.

In this study, to clarify the growth kinetics of reaction layers and investigate the interfacial properties between joint areas, Be and $\mathrm{F} 82 \mathrm{H}$ were joined by plasma sintering at various temperatures, and the mechanical properties of the joined materials were tested.

\section{Materials and Methods}

The starting material was $\mathrm{F} 82 \mathrm{H}$ ( $\mathrm{Fe}-8 \mathrm{Cr}-2 \mathrm{~W}-0.2 \mathrm{~V}-0.04 \mathrm{Ta}-0.1 \mathrm{C})$, which is a candidate structural material for a Japanese test blanket material and demonstration (DEMO) reactor. The F82H (BA12 heat, ID:BT2-1-4) was treated by normalizing at $1313 \mathrm{~K}$ for $40 \mathrm{~min}$ and then tempered at $1023^{\circ} \mathrm{C}$ for $60 \mathrm{~min}$ after hot rolling of an ingot material, and consisted of a tempered martensite structure [16]. The material was machined to a thickness of $17 \mathrm{~mm}$ and diameter of $20 \mathrm{~mm}$ with cutting accuracy of $\pm 1 \mu \mathrm{m}$ by an electrical discharge machine (Robocut $\alpha$-OiD, FANUC, Yamanashi, Japan). Be materials (S65, Materion, Mayfield Heights, OH, USA) of the same thickness and diameter were machined to a cylindrical rod with a diameter of $20 \mathrm{~mm}$ and thickness of $17 \mathrm{~mm}$. The joining areas of both $\mathrm{F} 82 \mathrm{H}$ and Be samples were polished by up to \#4000 silicon carbide ( $\mathrm{SiC}$ ) paper. To perform joining of two cylindrical materials, a plasma sintering (KE-PAS III, KAKEN Co., Ltd., Ibaraki, Japan) process was applied. After the two materials were placed in a graphite punch-and-die system, the Be and F82H samples were joined by plasma sintering at different sintering temperatures $(923,1023$, and $1123 \mathrm{~K}$ ) and at a pressure of $50 \mathrm{MPa}$ for $90 \mathrm{~min}$. To investigate the interfacial difference in the cross-section of the Be-F82H joint and the variation in the composition of the reaction layer, electron probe microscopic analysis (JXA-8530F, JEOL, Tokyo, Japan) with point and line analyses was conducted. In parallel to the point and line analyses, elemental mapping was conducted on the reaction layer with $\mathrm{Fe}, \mathrm{Cr}, \mathrm{W}$, and $\mathrm{Be}$.

To evaluate the mechanical properties of joined materials, four-point bending tests were conducted by an universal tester (AGX-10kNVD, Shimadzu, Kyoto, Japan), based on JIS R1601 with a crosshead speed of $0.5 \mathrm{~mm} / \mathrm{min}$ at room temperature using three samples per each condition of dimensions $3 \mathrm{~mm} \times 3 \mathrm{~mm} \times 35 \mathrm{~mm}$, and polished using \#1200 SiC paper. Furthermore, the fractural surface was observed by scanning electron microscopy (SEM)/EPMA (JXA-8530F, JEOL, Tokyo, Japan) to clarify the fracture behaviour of the joined samples.

\section{Results and Discussion}

Figure 1 shows the cross-sectional SEM images of the Be-F82H interfacial region joined by plasma sintering at $1023 \mathrm{~K}$ for 30, 60, and $90 \mathrm{~min}$. The reaction layers between Be and $\mathrm{F} 82 \mathrm{H}$ joined by plasma sintering under all conditions were observed. The thickness of the reaction layers increased as time increased. For the material joined at $1023 \mathrm{~K}$ for 30,60 , and $90 \mathrm{~min}$, the reaction layer thickness was 7.2, 9.3, and $12.8 \mu \mathrm{m}$, respectively.
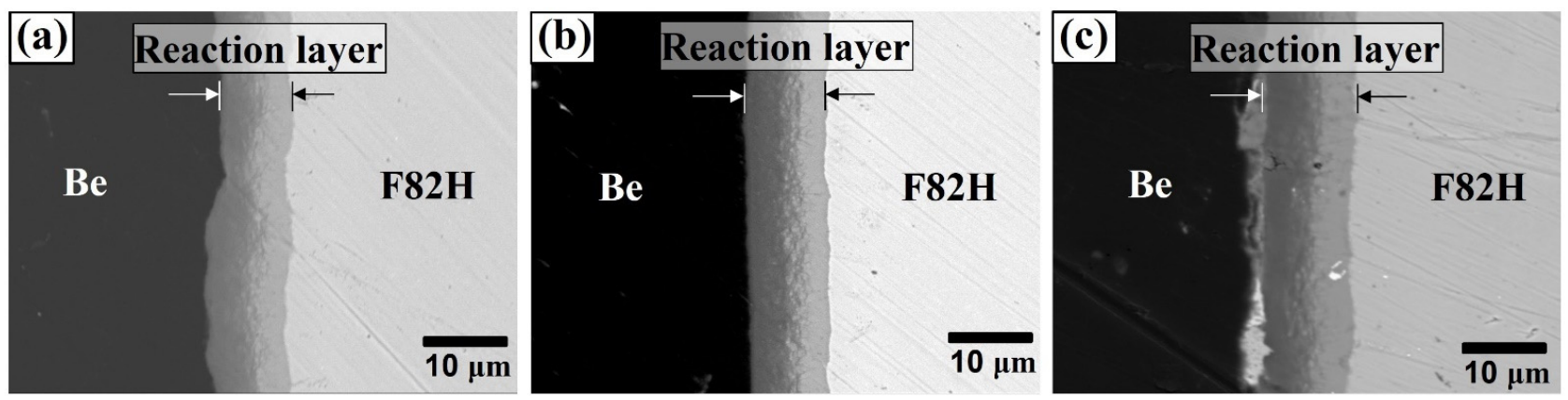

Figure 1. Cross-sectional SEM images of Be-F82H joints sintered at $1023 \mathrm{~K}$ for (a) $30 \mathrm{~min}$, (b) $60 \mathrm{~min}$, and (c) $90 \mathrm{~min}$. 
To understand the temperature dependence of the reaction layer, the thicknesses of the reaction layers for the materials joined at 923,1023, and $1123 \mathrm{~K}$ for 90 min were investigated, and the thickness was 6.8, 12.8, and $26.4 \mu \mathrm{m}$, respectively (Figure 2).
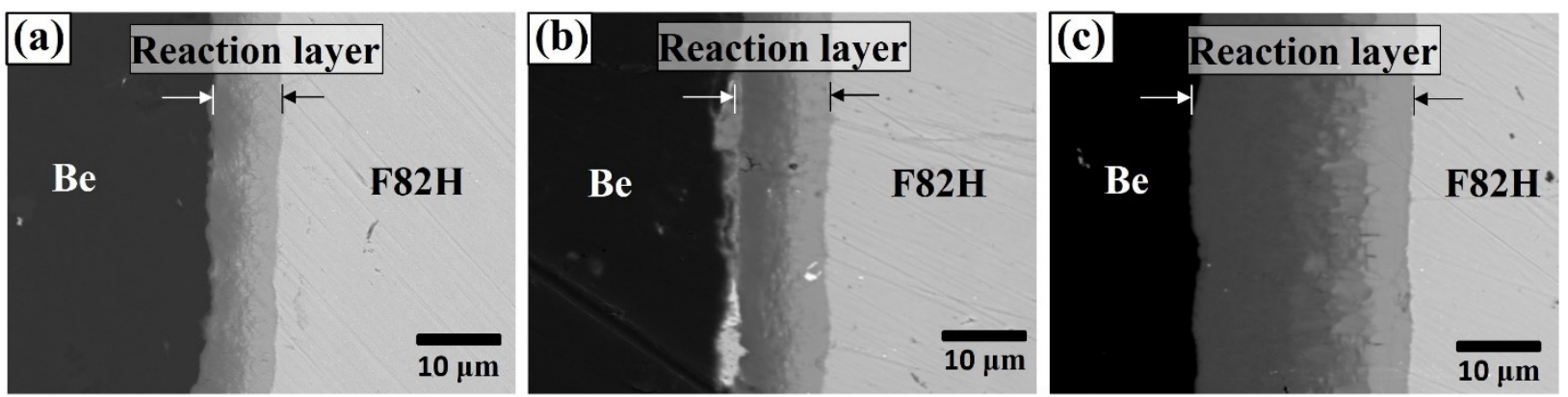

Figure 2. Cross-sectional SEM images of Be-F82H joints sintered at (a) $923 \mathrm{~K}$, (b) $1023 \mathrm{~K}$, and (c) $1123 \mathrm{~K}$ for $90 \mathrm{~min}$.

The thickness of a reaction layer between Be and F82H fabricated by the HIP process at $1023 \mathrm{~K}$ for $2 \mathrm{~h}$ was $6 \mu \mathrm{m}$ [17], which slightly differs from the result herein. We speculate that plasma sintering facilitates the diffusion reaction more effectively than HIP since on-off direct current (DC) pulse promotes the sintering process, including effective discharge between particles of powder which leads to an electric field diffusion effect $[18,19]$.

To clarify the chemical composition of the reaction layers, SEM observation with backscattered electrons and point analyses were performed on the layers (Figure 3). The reaction layer consists mainly of Be and Fe elements and small amounts of $\mathrm{Cr}$ and $\mathrm{W}$. The concentration gradient of $\mathrm{Fe}$ and Be was determined. This concentration gradient is attributed to the formation of different intermetallic compounds, including $\mathrm{Be}_{12} \mathrm{Fe}_{2} \mathrm{Be}_{5} \mathrm{Fe}$, and $\mathrm{Be}_{2} \mathrm{Fe}$ (Table 1). The Be-enriched compounds detected at the measurement points went into the Be matrix.

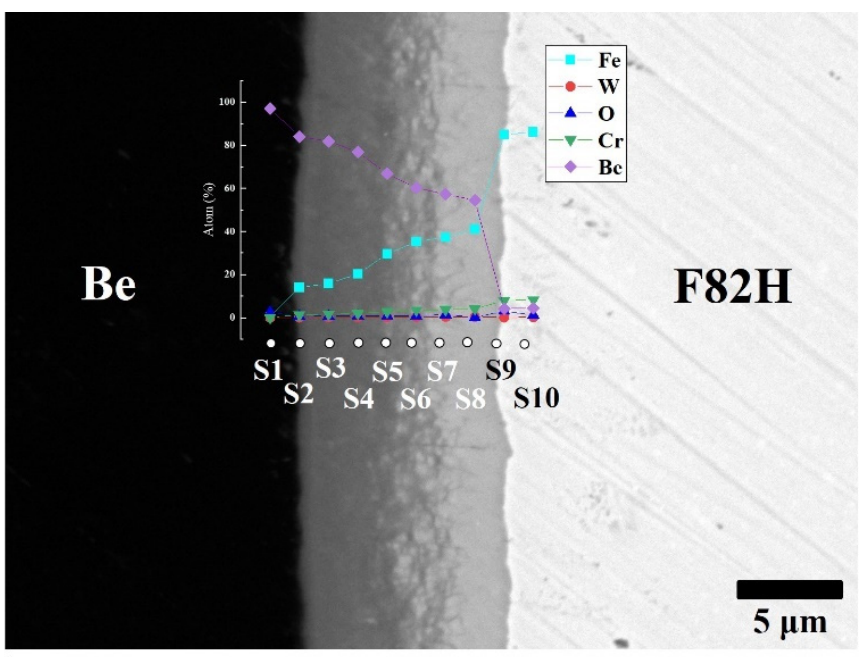

Figure 3. Cross-sectional SEM image of F82H-Be joints sintered at $1023 \mathrm{~K}$ for 60 min with point analyses from $\mathrm{S} 1$ to $\mathrm{S} 10$ with atomic $\%$ of $\mathrm{Fe}, \mathrm{W}, \mathrm{O}, \mathrm{Cr}$ and $\mathrm{Be}$.

Table 1. Chemical composition (at.\%) of each point and estimated compounds.

\begin{tabular}{cccccccc}
\hline \multirow{2}{*}{ Measuring Point } & \multicolumn{3}{c}{ Composition (at.\%) } & \multicolumn{2}{c}{ Estimated Compounds } \\
\cline { 2 - 6 } & Be & Fe & Cr & W & O & Be \\
\hline S1 & 97.16 & 0.44 & 0.02 & 0.00 & 2.38 & 0.62 & $\mathrm{Be}_{12} \mathrm{Fe}_{2}$ \\
\hline S2 & 84.03 & 14.02 & 1.23 & 0.10 & 0.12 & $\mathrm{Be}_{12} \mathrm{Fe}$ \\
\hline S3 & 81.91 & 15.80 & 1.50 & 0.68 & \\
\hline
\end{tabular}


Table 1. Cont.

\begin{tabular}{|c|c|c|c|c|c|c|}
\hline \multirow{2}{*}{ Measuring Point } & \multicolumn{5}{|c|}{ Composition (at.\%) } & \multirow{2}{*}{ Estimated Compounds } \\
\hline & $\mathrm{Be}$ & $\mathrm{Fe}$ & $\mathrm{Cr}$ & $\mathbf{W}$ & $\mathbf{O}$ & \\
\hline S4 & 76.88 & 20.25 & 1.89 & 0.17 & 0.80 & $\mathrm{Be}_{12} \mathrm{Fe}, \mathrm{Be}_{5} \mathrm{Fe}$ \\
\hline S5 & 66.78 & 29.53 & 2.64 & 0.23 & 0.83 & $\mathrm{Be}_{5} \mathrm{Fe}, \mathrm{Be}_{2} \mathrm{Fe}$ \\
\hline S6 & 60.21 & 35.25 & 3.40 & 0.32 & 0.82 & $\mathrm{Be}_{5} \mathrm{Fe}, \mathrm{Be}_{2} \mathrm{Fe}$ \\
\hline S7 & 57.29 & 37.34 & 3.65 & 0.35 & 1.37 & $\mathrm{Be}_{2} \mathrm{Fe}$ \\
\hline $\mathrm{S} 8$ & 54.53 & 41.03 & 4.01 & 0.34 & 0.08 & $\mathrm{Be}_{2} \mathrm{Fe}$ \\
\hline S9 & 3.13 & 86.14 & 7.89 & 1.88 & 0.96 & $\mathrm{Be}_{2} \mathrm{Fe}, \mathrm{F} 82 \mathrm{H}$ \\
\hline S10 & 0.39 & 89.16 & 8.19 & 1.68 & 0.57 & $\mathrm{~F} 82 \mathrm{H}$ \\
\hline
\end{tabular}

The analytical result is consistent with the elemental mapping of $\mathrm{Be}, \mathrm{Fe}, \mathrm{Cr}, \mathrm{W}$, and $\mathrm{N}$ elements using an electron microprobe analyser (EPMA) (Figure 4). The concentration gradient was dependent on the thickness of the layer. In the reaction layer, two or three layers with different compositions were identified. $\mathrm{Be}_{12} \mathrm{Fe}, \mathrm{Be}_{5} \mathrm{Fe}$, and $\mathrm{Be}_{2} \mathrm{Fe}$ with small amounts of $\mathrm{Cr}$ and $\mathrm{W}$ were detected (Table 1). Additionally, concentration gradients of $\mathrm{Cr}$ and $\mathrm{W}$ diffused from $\mathrm{F} 82 \mathrm{H}$ were observed on the reaction layer. No remarkable depletion area was observed near the reaction layer.
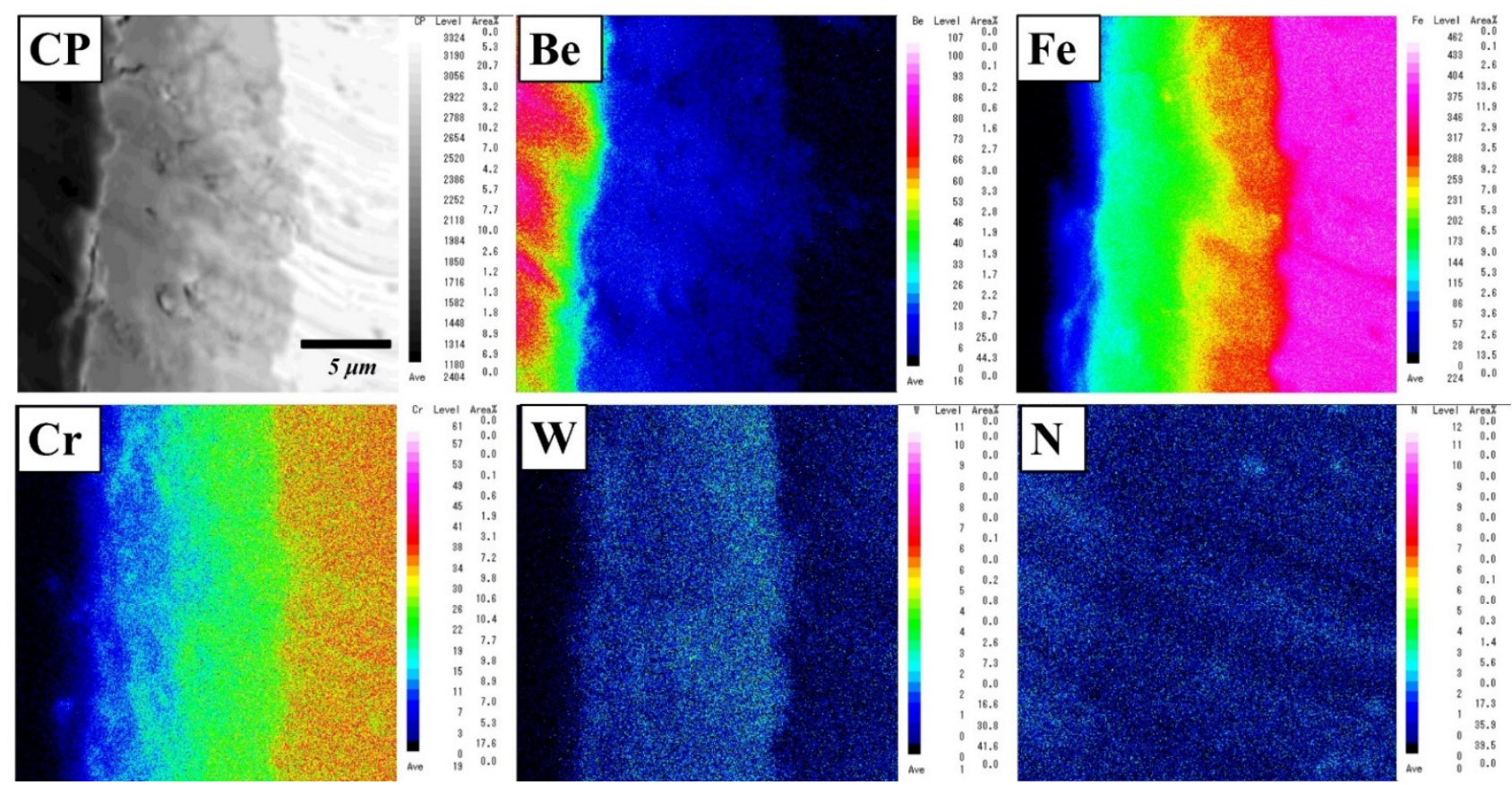

Figure 4. Elemental mapping of a reaction layer in a Be-F82H joint sintered at $1023 \mathrm{~K}$ for $90 \mathrm{~min}$.

Since diffusion generally depends on time and temperature, it is vital to understand the joining time and temperature effect on the thickness of the reaction layer. Thus, the time dependence of the thickness of the reaction layer at $1023 \mathrm{~K}$ was investigated (Figure 5). The thickness of the reaction layer formed by reaction diffusion was proportional to the square root of the diffusion time (s), which is in good agreement with the results of previous studies $[20,21]$. The fitting result shows good linearity, implying the layer growth obeys the parabolic law, indicative of a diffusion-controlled growth, expressed as $1=\mathrm{k} \cdot \mathrm{t}^{1 / 2}$. 


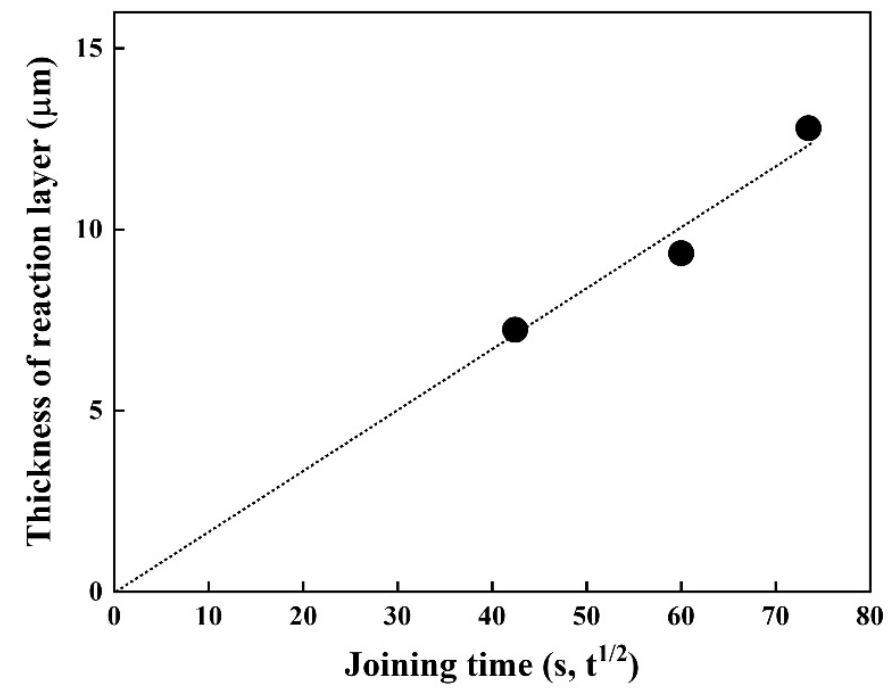

Figure 5. Thickness of the reaction layer as a function of joining time at $1023 \mathrm{~K}$.

Further, the temperature dependence of the reaction layer was evaluated using the materials joined at $923,1023,1123 \mathrm{~K}$ for $90 \mathrm{~min}$, and the growth rate constant $\left(\mathrm{m}^{2} \cdot \mathrm{s}\right)$ was calculated. The Arrhenius plot of the growth rate constants for the reaction layer is shown in Figure 6.

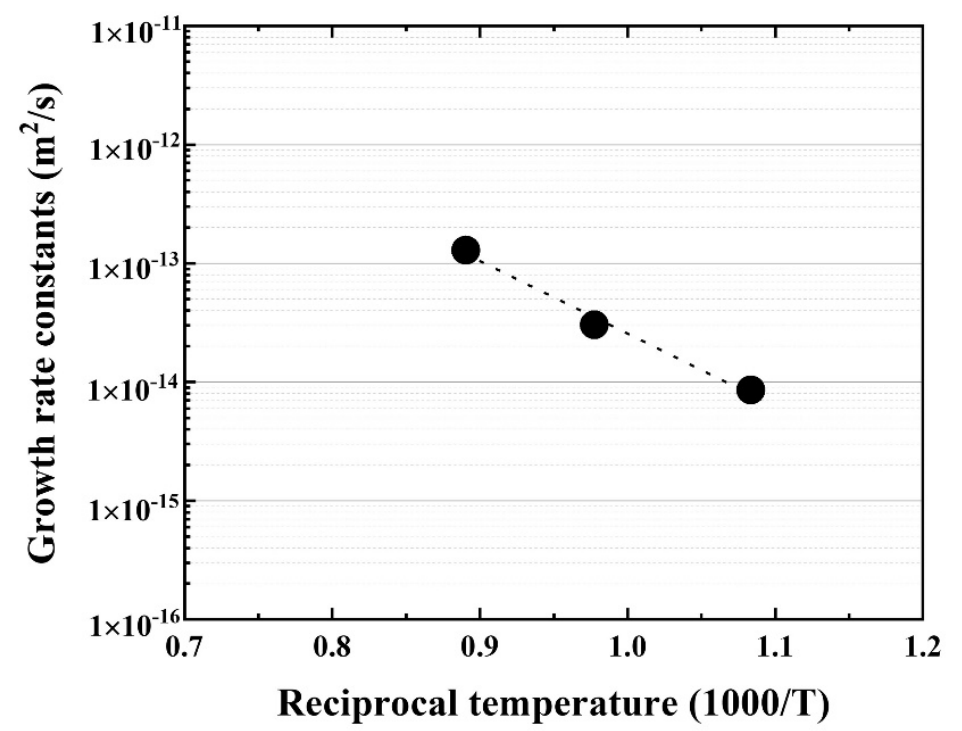

Figure 6. Arrhenius plot of the reaction layer as a function of reciprocal temperature.

Good linearity was obtained, and the activation energy for the growth rate of the reaction layer was $116.2 \mathrm{~kJ} / \mathrm{mol}$, which is similar to that of $\mathrm{Cu}-\mathrm{Al}$ intermetallic compound [22] and lower than that of $\beta-\mathrm{Ti}$ in Ti alloys [20]. The bonding strength of the Be/F82H joint was evaluated (Figure 7). It indicates that the bonding strength is inversely proportional to the thickness of the joint between $\mathrm{Be}$ and $\mathrm{F} 82 \mathrm{H}$. This inverse trend is because the increased thickness of the reaction layer comprising $\mathrm{Be}_{12} \mathrm{Fe}_{2} \mathrm{Be}_{5} \mathrm{Fe}$, and $\mathrm{Be}_{2} \mathrm{Fe}$ decreased the bonding strength, which is in good agreement with the results in [17]. It is noted that all specimens were fractured at the joined area, in other words, it does not depend on the structure variation of the substrates, $\mathrm{F} 82 \mathrm{H}$ and $\mathrm{Be}$, even though those specimens were heat-treated at a temperature higher than the tempering temperature at $1023 \mathrm{~K}$. 


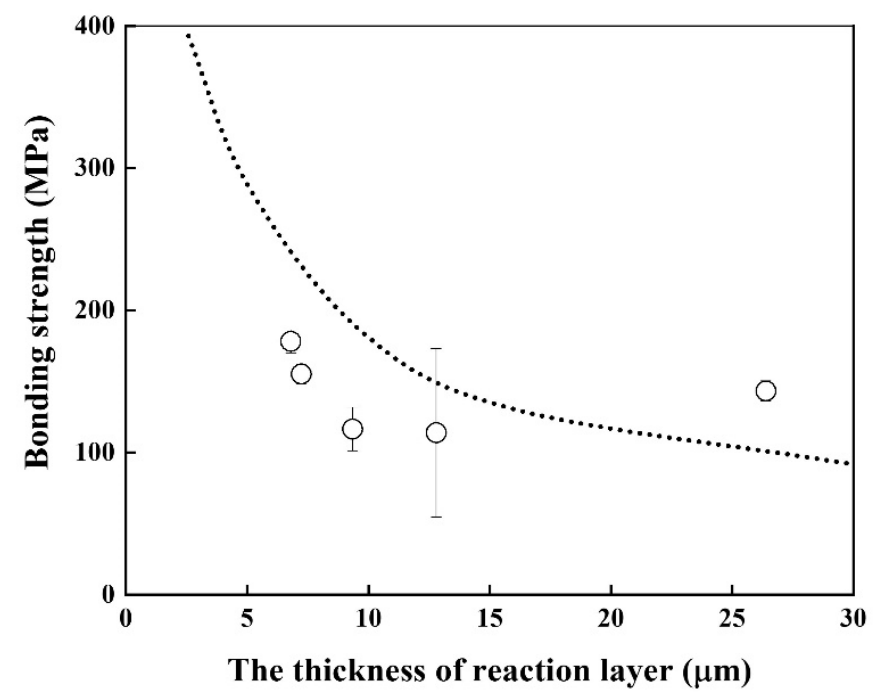

Figure 7. Bonding strength of joints as a function of the reaction layer thickness (Dot line indicates the result in [17]).

Regarding the fracture surface, for the materials joined for 30 min, many smallsize grains were delaminated (Figure $8 \mathrm{~b}$ ) as seen with black colour. However, as the joining time and temperature increased, delaminations along the grain boundaries and the cleavage facets were observed. (Figure 8e,g), whereas the fraction of grain delamination decreased. This difference in delamination behaviour can be attributed to the variation in the bonding strength. It can be concluded that the increased thickness of the reaction layer comprising $\mathrm{Be}_{12} \mathrm{Fe}, \mathrm{Be}_{5} \mathrm{Fe}$, and $\mathrm{Be}_{2} \mathrm{Fe}$ decreased the bonding strength, since the intermetallic compounds are much more brittle than substrates.
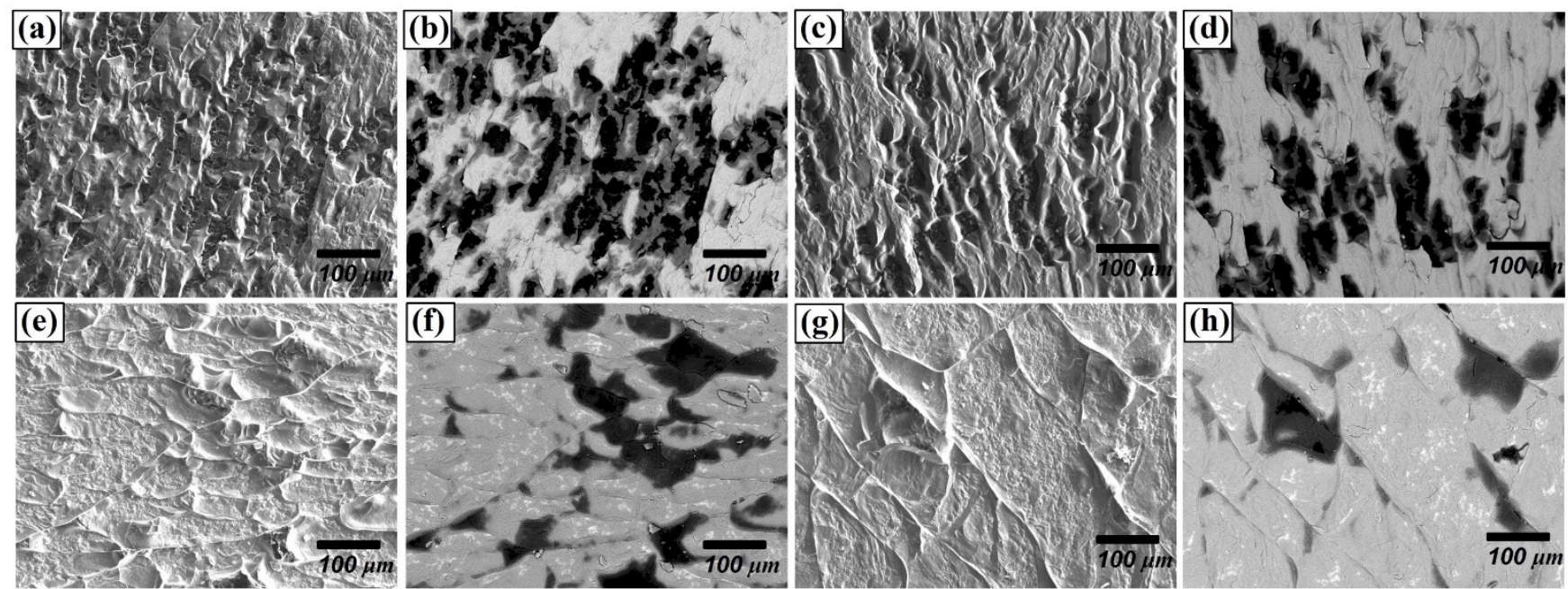

Figure 8. Fracture surface of F82H-Be joint at $1023 \mathrm{~K}$ for (a,b) $30 \mathrm{~min}$, (c,d) $60 \mathrm{~min}$, (e,f) $90 \mathrm{~m}$, and (g,h) $1123 \mathrm{~K}$ for $90 \mathrm{~min}$, (a,c,e,g: secondary electron images, $\mathbf{b}, \mathbf{d}, \mathbf{f}, \mathbf{h}$ : backscattered electron images).

\section{Conclusions}

Be and F82H were joined under various conditions to investigate the growth kinetics of the reaction layer and the mechanical strength of joined materials. As the joining time and temperature increased, the thickness of the reaction layer increased. Line analyses and elemental mapping by EPMA revealed that the reaction layer consists of Be-Fe intermetallic compounds, including $\mathrm{Be}_{12} \mathrm{Fe}, \mathrm{Be}_{5} \mathrm{Fe}$, and $\mathrm{Be}_{2} \mathrm{Fe}$, with small amounts of $\mathrm{Cr}$ and $\mathrm{W}$ diffused from the $\mathrm{F} 82 \mathrm{H}$ matrix. 
Owing to the time dependence of the thickness of the reaction layer, the layer growth of Be-Fe intermetallic compounds predominantly obeys the parabolic law. Furthermore, by evaluating the temperature dependence of the thickness of the reaction layer, we found good linearity, and the activation energy for the growth of the reaction layer was $116.2 \mathrm{~kJ} / \mathrm{mol}$.

Finally, the bonding strength of the joined materials was inversely proportional to the thickness of the reaction layer. The difference in the fracture behaviour induced by either the delamination of grains or delamination along grain boundaries is attributed to the difference in the bonding strength.

Author Contributions: Conceptualization, J.-H.K. and T.H.; methodology, J.-H.K. and T.H.; validation, J.-H.K.; formal analysis, T.H.; writing-original draft preparation, J.-H.K.; writing-review and editing, J.-H.K. and T.H.; supervision, M.N. All authors have read and agreed to the published version of the manuscript.

Funding: This work was supported by JSPS KAKENHI Grant Number 21 H01071.

Institutional Review Board Statement: Not applicable.

Informed Consent Statement: Not applicable.

Data Availability Statement: Not applicable.

Conflicts of Interest: The authors declare no conflict of interest.

\section{References}

1. Miriyev, A.; Grutzner, S.; Kruger, L.; Kalabukhov, S.; Frage, N. Bonding of TRIP-steel/ $\mathrm{Al}_{2} \mathrm{O}_{3}$-(3Y)-TZP composites and (3Y)-TZP ceramic by a spark plasam sintering (SPS) apparatus. Materials 2016, 9, 558. [CrossRef] [PubMed]

2. Liu, G.; Zhang, X.; Yang, J; Qiao, G. Recent advances in joining of SiC-based materials (monolithic SiC and SiCf/SiC composites): Joining processs, joint strength, and interfacial behavior. J. Adv. Ceram. 2019, 8, 19-38. [CrossRef]

3. Ben-Ayoun, D.; Sadia, Y.; Gelbstein, Y. Compatibility between Co-Metallized PbTe thermoelectric legs and an Ag-Cu-In brazing alloy. Materials 2018, 11, 99. [CrossRef]

4. Kustron, P.; Korzeniowski, M.; Piwowarczyk, T.; Sokolowski, P. Development of resistance spot welding processes of metal-plastic composites. Materials 2021, 14, 3233. [CrossRef]

5. Jadhav, A.D.; Padture, N.P.; Jordan, E.H.; Gell, M.; Miranzo, P.; Fuller, D.R., Jr. Low-thermal-conductivity plasma-sprayed thermal barrier coatings with engineered microstructures. Acta Mater. 2006, 54, 3343-3349. [CrossRef]

6. Cao, R.; Chang, J.H.; Huang, Q.; Zhang, X.B.; Yan, Y.J.; Chen, J.H. Behaviors and effects of Zr coating on welding-brazing process of Al-Steel and Mg-steel dissimilar metals. J. Manuf. Process. 2018, 31, 674-688. [CrossRef]

7. Tanner, L.E.; Okamoto, H. The Be-Fe system. Bull. Alloy. Phase Diagr. 1988, 9, 494-508. [CrossRef]

8. Hernandez, F.A.; Pereslavtsev, P.; Zhou, G.; Neuberger, H.; Rey, J.; Kang, Q.; Boccaccini, L.V.; Bubelis, E.; Moscato, I.; Dongiovanni, D. An enhanced, near-term HCPB design as driver blanket for the EU DEMO. Fusion Eng. Des. 2019, 146, 1186-1191. [CrossRef]

9. Hunt, R.M.; Goods, S.H.; Ying, A.; Dorn, C.K.; Abdou, M. Evaluation of $\mathrm{Cu}$ as an interlayer in Be/F82H diffusion bonds for ITER TBM. J. Nucl. Mater. 2011, 417, 89-92. [CrossRef]

10. Hunt, R.M.; Good, S.H.; Ying, A.; Dorn, C.K.; Abdou, M. Diffusion bonding beryllium to reduced activation ferritic martensitic steel: Development of processes and techniques. Fusion Eng. Des. 2012, 87, 1550-1557. [CrossRef]

11. Kim, J.-H.; Nakamichi, M. Effect of plasma-sintering consolidation on the reactivity of beryllium. Fusion Eng. Des. 2014, 89, 1440-1443. [CrossRef]

12. Kim, J.-H.; Nakamichi, M. Effect of grain size on the hardness and reactivity of plasma-sintered beryllium. J. Nucl. Mater. 2014, 453, 22-26. [CrossRef]

13. Kim, J.-H.; Nakamichi, M. Comparative study on arc-melting and plasma-sintered beryllides. J. Alloys Compd. 2013, 546, 171-175. [CrossRef]

14. Kim, J-H.; Nakamichi, M. Comparative study of sinterability and tehrmal stability in plasma-sintered niobium and vanadium beryllides. J. Alloys Compd. 2015, 638, 277-281. [CrossRef]

15. Kim, J.-H.; Nakamichi, M. Effect of grain size on the sinterability and reactivity of vanadium-beryllium intermetallic compounds. Fusion Eng. Des. 2019, 144, 93-96. [CrossRef]

16. Sakasegawa, H.; Tanigawa, H.; Kano, S.; Abe, H. Material properties of the F82H melted in an electric are furnace. Fusion Eng. Des. 2015, 98-99, 2068-2071. [CrossRef]

17. Hirose, T.; Ando, M.; Ogiwara, H.; Tanigawa, H.; Enoeda, M.; Akiba, M. Interfacial properties of HIP joints between beryllium and reduced activation ferritic/martensitic steel. Fusion Eng. Des. 2010, 85, 809-812. [CrossRef]

18. Olevsky, E.A. Impact of thermal diffusion on densification during SPS. J. Am. Ceram. Soc. 2009, 92, S122-S132. [CrossRef]

19. Lin, D.; Yuan, L.; Zhang, P.; Zuo, F.; Plucknett, K.; Grasso, S.; Wang, H.; Lin, H. Densificiation and phase transformation in multi-layered graded Si3N4-TiN components produced by field-assisted sintering. Materials 2019, 12, 2900. [CrossRef] [PubMed] 
20. Taguchi, O.; Tiwari, G.P.; Iijima, Y. Growth kinetic of $\beta$-Ti Solid Solution in Reaction Diffusion. Mater. Trans. 2003, 44, 83-88. [CrossRef]

21. Cooke, K.O.; Richardson, A.; Khan, T.I.; Shar, M.A. High-temperature diffusion bonding of Ti-6Al-4V and super duplex stainless steel using a $\mathrm{Cu}$ interlayer embedded with alumina nanoparticles. J. Manuf. Mater. Process. 2020, 4, 3. [CrossRef]

22. Xu, H.; Liu, C.; Silberschmidt, V.V.; Chen, Z. Growth of Intermetallic Compounds in Thermosonic Copper Wire Bonding on Aluminum Metallization. J. Electron. Mater. 2010, 39, 124-131. [CrossRef] 